\section{Infra-Red in Photomicrography}

THe photography of small insects by transmitted light has hitherto been complicated by the necessity of employing screens transmitting only the red end of the spectrum, if detail of both body and wings is to be secured on the same plate. Recent improvements in the sensitising of plates to infra-red enable much darker screens to be used with relatively shorter exposures. An interesting example of this has recently been given by Mr. A. E. Smith (Watson's Micro. Rec., No. 27) who publishes a photograph of a phorid fly in which the venation of the wings and the structure of the external genitalia are shown at the same time as the minute detail of body arma. ture. The exposure of only five seconds through the almost opaque Ilford infra-red screen is a remarkable tribute to the speed of the plates, which quite evidently open a new field for the photomicrographic worker in all subjects.

\section{Memorial to Prof. W. D. Halliburton, F.R.S.}

ON December 17, Sir F. Gowland Hopkins unveiled a plaque which has been placed in the Halliburton laboratory of physiology at King's College, London, in memory of Prof. W. D. Halliburton, who was professor of physiology at the College from 1890 until 1923. When Prof. Halliburton was appointed, the Iaboratory was on the Embankment in small and badly lit rooms where Ferrier and Lister had worked. Yet, by his enthusiasm, he managed to attract many young physiologists to the College. The present laboratory is the result of his great efforts during his tenure of office as professor of physiology. Prof. Halliburton was elected a fellow of the Royal Society in 1891 and died on May 21, 1931, aged seventy years.

\section{Duddell Type Oscillographs}

THE Cambridge Instrument Co., Ltd., has issued a new list of oscillographs developed from the Duddell type (List No.118). As usual in the catalogues of this firm, there is a valuable discussion of the design of the instruments, but the present list is noteworthy for the large number of examples of their use. These include the study of wireless 'echoes', of speech wave forms and of mechanical vibrations in turbine blading. In view of the modern development of large units in electrical engineering, there is a particular interest in the installations for investigating short-circuit and circuit-breaking phenomena and in the reproductions of very beautiful oscillograms obtained by their use.

\section{Christmas Lectures at the Royal Institution}

THe Christmas Lectures at the Royal Institution are to be given this year, starting on December 27, by Prof. Rankine. Prof. Rankine, who is president of the Physical Society, has carried out laboratory researches on the determination of the sizes of numerous gaseous molecules, as deduced from measurements of viscosity. During the War he investigated the possibilities of transmitting speech by light, using the selenium cell, and invented an instrument for this purpose, the photophone. In recent years his scientific work has taken him farther afield. He has been concerned in the latest developments of the science of geophysics, particularly in regard to its use in prospecting for minerals, including oil, and has made expeditions to Persia and Australia in connexion with this work. The subject of Prof. Rankine's lectures, 'The Round of the Waters', is full of possibilities. The subject lends itself to experiment in a great variety of ways, and this, the one hundred and seventh course of Christmas Lectures, should certainly not be wanting in interest and instructiveness.

\section{Announcements}

At a meeting of the Royal Academy of Belgium held on December 15, Prof. P. Zeeman, professor of experimental physics in the University of Amsterdam, and Prof. T. Levi-Civita, professor of rational mechanics in the University of Rome, were elected foreign associates of the Academy.

The Hopkins prize for the period 1924-27 has been uwarded by the Cambridge Philosophical Society to Prof. G. I. Taylor, Yarrow research professor of the Royal Society, for his researches on hydrodynamics and on the deformation of crystals; and the prize for the period 1927-30 to Prof. P. A. M. Dirac, Lucasian professor of mathematics in the University of Cambridge, for his researches on the theory of quantum mechanics.

We have received the report of the Victorian Bush Nursing Association for the year ended June 30 last. This Association, of which Sir James Barrett is secretary, provides trained nurses and other requisites for sick and injured persons in country towns and districts. It is run on a co-operative basis, a householder paying a small annual subscription, usually $£ 1$, and has 65 nursing centres and 29 cottage hospitals. Maternity and child welfare are important branches of the work. In spite of the financial stringency in Australia, the Association had a credit balance of $£ 1,900$ at the end of the year. Full reports are given of the activities in the various centres.

Applicatrons are invited for the following appointments, on or before the dates mentioned :-A male junior assistant metallurgist for the Royal Small Arms Factory, Enfield Lock, and a male junior assistant chemist at the Royal Gunpowder Factory, Waltham Abbey-The Principal Clerk, Central Office, Royal Gunpowder and Small Arms Factories, Enfield Lock, Middlesex (Jan. 7). An assistant in the Department of Manuscripts and Records of the National Library of Wales-The Librarian, National Library of Wales, Aberystwyth-(Jan. 16). A University professor of physics at Birkbeck CollegeThe Academic Registrar, University of London, S.W.7 (Feb. 10). A director (professor) of the Research Laboratory in Botany at the University of MadrasThe Registrar, University of Madras, Triplicane, P.O. (April 1) ; further information from the High Commissioner for India.

$$
\text { No. 3295, VoL. 130] }
$$

